\title{
Hunter versus CIE color measurement systems for analysis of milk-based beverages
}

\author{
Ni Cheng, ${ }^{*}$ David M. Barbano, $\dagger^{1}$ and Mary Anne Drake* \\ *Southeast Dairy Foods Research Center, North Carolina State University, Raleigh 27695 \\ †Northeast Dairy Foods Research Center, Department of Food Science, Cornell University, Ithaca, NY 14853
}

\begin{abstract}
The objective of our work was to determine the differences in sensitivity of Hunter and International Commission on Illumination (CIE) methods at 2 different viewer angles $\left(2\right.$ and $\left.10^{\circ}\right)$ for measurement of whiteness, red/green, and blue/yellow color of milk-based beverages over a range of composition. Sixty combinations of milk-based beverages were formulated (2 replicates) with a range of fat level from 0.2 to $2 \%$, true protein level from 3 to $5 \%$, and casein as a percent of true protein from 5 to $80 \%$ to provide a wide range of milkbased beverage color. In addition, commercial skim, 1 and $2 \%$ fat high-temperature, short-time pasteurized fluid milks were analyzed. All beverage formulations were HTST pasteurized and cooled to $4^{\circ} \mathrm{C}$ before analysis. Color measurement viewer angle (2 vs. $\left.10^{\circ}\right)$ had very little effect on objective color measures of milkbased beverages with a wide range of composition for either the Hunter or CIE color measurement system. Temperature $\left(4,20\right.$, and $\left.50^{\circ} \mathrm{C}\right)$ of color measurement had a large effect on the results of color measurement in both the Hunter and CIE measurement systems. The effect of milk beverage temperature on color measurement results was the largest for skim milk and the least for $2 \%$ fat milk. This highlights the need for proper control of beverage serving temperature for sensory panel analysis of milk-based beverages with very low fat content and for control of milk temperature when doing objective color analysis for quality control in manufacture of milk-based beverages. The Hunter system of color measurement was more sensitive to differences in whiteness among milk-based beverages than the CIE system, whereas the CIE system was much more sensitive to differences in yellowness among milkbased beverages. There was little difference between the Hunter and CIE system in sensitivity to green/red color of milk-based beverages. In defining milk-based
\end{abstract}

Received November 26, 2017.

Accepted February 10, 2018.

${ }^{1}$ Corresponding author: dmb37@cornell.edu beverage product specifications for objective color measures for dairy product manufacturers, the viewer angle, color measurement system (CIE vs. Hunter), and sample measurement temperature should be specified along with type of illuminant.

Key words: color, milk, whiteness

\section{INTRODUCTION}

Color influences sensory perception and consumer preference of food products. A review by Clydesdale (1993) summarized studies focusing on color effects on taste thresholds, sweetness perception, pleasantness, salt perception, preference, and acceptability and perception of food and beverages in an elderly population. More recently, Chung (2009) studied consumer preference of full-fat, low-fat, and lactose-free milk pasteurized by UHT or low-temperature, long-time, and milks with higher whiteness and lower yellowness were perceived as having higher flavor intensity. McCarthy et al. (2017) determined visual and tasting difference thresholds for fat in fluid milk followed by paired preference testing with follow-up interviews and reported better color or color/whiteness was an important reason that skim milk, $2 \%$ fat milk, and whole milk drinkers all preferred higher fat level milks. Further, consumers were less sensitive to differences in fat concentration when correlated appearance differences were removed, confirming the role of appearance and color on sensory properties of fluid milk.

Phillips et al. (1995a), Phillips and Barbano (1997), and Misawa et al. (2016) concluded that objective measurement of whiteness showed correlations with several appearance, texture, and flavor sensory descriptors for low-fat milks. Phillips et al. (1995a) found that increasing milk fat level (0.06 to $2.0 \%)$ increased Lvalue (whiteness) and decreased a-value (greenness to redness) and b-value (blueness to yellowness) of milk, which were well correlated with perceived color of lowfat milk by sensory analysis with trained panels. Phillips et al. (1995a) also reported using trained panelists that milk appearance largely influenced the perceived 
mouthfeel of milk. This confirmed the results from Pangborn et al. (1985) that visual cues were important for milk differentiation based on fat level. McCarthy et al. (2017) confirmed the importance of color with consumer panelists. Addition of nonfat dry milk (0 to $2 \%$ ) to low-fat milk showed no difference in color and sensory perception of milk (Phillips et al., 1995b), whereas the addition of titanium dioxide made skim milk whiter and increased the trained panel sensory scores for milk appearance descriptors (Phillips and Barbano, 1997). Increasing true protein (TP) level (Quiñones et al., 1997, 1998) and casein as a percentage of true protein (Misawa et al., 2016) increased whiteness of low-fat milks and caused the sensory perception of these low fat milks to be more similar to higher fat level milks.

Hunter (L, a, b) and International Commission on Illumination (CIE) L*, $\mathrm{a}^{*}$, and $\mathrm{b}^{*}$ color measurement systems or color space are primarily used in food, textile, and pharmacy industries. Both color measurement systems were developed based on the CIE (x, y, z) 1931 system to generate a more uniform color space for color measurement with specific calculation equations for $\mathrm{L} / \mathrm{L}^{*}, \mathrm{a} / \mathrm{a}^{*}$, and $\mathrm{b} / \mathrm{b}^{*}$ (Hunter and Harold, 1987). The primary difference in these 2 color system is the Hunter $(\mathrm{L}, \mathrm{a}, \mathrm{b})$ equations use the square root of CIE $(\mathrm{x}, \mathrm{y}, \mathrm{z})$ for $\mathrm{L}, \mathrm{a}, \mathrm{b}$ calculation, whereas the CIE $\left(\mathrm{L}^{*}, \mathrm{a}^{*}\right.$, and $\left.\mathrm{b}^{*}\right)$ equations use the cubic root (Hunter and Harold, 1987). However, both color systems are not ideally uniform. The Hunter $(\mathrm{L}, \mathrm{a}, \mathrm{b})$ system is more sensitive in measuring blueness, whereas the CIE ( $\mathrm{L}^{*}$, $\left.a^{*}, b^{*}\right)$ system is more sensitive in measuring yellowness and dark colors (CIE, 1978; Hunter and Harold, 1987; Hunter Associates Laboratory, 2012). Today, the $\mathrm{L} / \mathrm{L}^{*}, \mathrm{a} / \mathrm{a}^{*}$, and $\mathrm{b} / \mathrm{b}^{*}$ values can all be obtained easily from colorimeter software and the most repeatable and sensitive metrics can be selected for use by an analyst. However, it is not always clear if the Hunter or CIE color measurement system is the best for analysis of milk-based beverages. The objective of our work was to determine the differences in sensitivity of Hunter and CIE methods at 2 different viewer angles for measurement of whiteness, red/green, and blue/yellow color of milk-based beverages over a range of composition.

\section{MATERIALS AND METHODS}

\section{Experimental Design}

Population of Beverage Formulations and Commercial Milks. Beverage formulations were based on a complete balanced 3 factor (fat, TP, and casein as a percentage of TP) design with 3 fat levels $(0.2,1.0$, and $2.0 \%), 4$ TP levels $(3.00,3.67,4.34$, and $5.00 \%$ ) within each fat level and 5 casein as a per-
Table 1. Formulation design for $0.2,1.0$, and $2.0 \%$ fat level milk protein beverages with variation in casein as a percentage of true protein (CN\% TP) of 5, 25, 50, 75, and $80 \%$ at true protein (TP) levels of $3.00,3.67,4.34$, and $5.00 \%$ within each fat level

\begin{tabular}{|c|c|c|c|c|c|}
\hline \multirow{2}{*}{$\begin{array}{l}\text { Fat } \\
(\%)\end{array}$} & \multicolumn{4}{|c|}{$\mathrm{TP}(\%)$} & \\
\hline & 3.00 & 3.67 & 4.34 & 5.00 & \\
\hline \multirow[t]{5}{*}{0.2} & 5 & 5 & 5 & 5 & $\mathrm{CN} \% \mathrm{TP}$ \\
\hline & 25 & 25 & 25 & 25 & $\mathrm{CN} \% \mathrm{TP}$ \\
\hline & 50 & 50 & 50 & 50 & $\mathrm{CN} \% \mathrm{TP}$ \\
\hline & 75 & 75 & 75 & 75 & $\mathrm{CN} \% \mathrm{TP}$ \\
\hline & 80 & 80 & 80 & 80 & $\mathrm{CN} \% \mathrm{TP}$ \\
\hline \multirow[t]{5}{*}{1.0} & 5 & 5 & 5 & 5 & $\mathrm{CN} \% \mathrm{TP}$ \\
\hline & 25 & 25 & 25 & 25 & $\mathrm{CN} \% \mathrm{TP}$ \\
\hline & 50 & 50 & 50 & 50 & $\mathrm{CN} \% \mathrm{TP}$ \\
\hline & 75 & 75 & 75 & 75 & $\mathrm{CN} \% \mathrm{TP}$ \\
\hline & 80 & 80 & 80 & 80 & $\mathrm{CN} \% \mathrm{TP}$ \\
\hline \multirow[t]{5}{*}{2.0} & 5 & 5 & 5 & 5 & $\mathrm{CN} \% \mathrm{TP}$ \\
\hline & 25 & 25 & 25 & 25 & $\mathrm{CN} \% \mathrm{TP}$ \\
\hline & 50 & 50 & 50 & 50 & $\mathrm{CN} \% \mathrm{TP}$ \\
\hline & 75 & 75 & 75 & 75 & $\mathrm{CN} \% \mathrm{TP}$ \\
\hline & 80 & 80 & 80 & 80 & $\mathrm{CN} \% \mathrm{TP}$ \\
\hline
\end{tabular}

centage of true protein $(\mathbf{C N} \% \mathbf{T P})$ levels $(5,25,50$, 75 , and $80 \%$ ) within each protein level as shown in Table 1. The formulation, sensory, and analytical work was done in 1 wk for each fat level and the formulation, processing, and analysis were replicated for all the treatments within each fat level in a second week, for a total of $6 \mathrm{wk}$ of processing. Color of commercial skim, 1 and $2 \%$ fat milks was also evaluated using the same analysis methods. There were 2 replicates of the commercial milk at all 3 fat levels for color analysis by both methods.

Comparison of Hunter Versus CIE Color Metrics. The goal of this data collection was to determine the effect of viewer angle $\left(2\right.$ vs. $\left.10^{\circ}\right)$ and color measurement system (Hunter vs. CIE) for evaluation of milk-based beverage color and was determined by the following comparison. For a color term, within each color metrics, the value differences observed at $2^{\circ}$ and $10^{\circ}$ viewer angles in response to changes in beverage composition were compared, whereas within each viewer angles, the value differences obtained from Hunter and CIE systems in response to changes in beverage compositions were compared to determine if the color differences among treatments were different under different objective color measurement approaches.

Effect of Processing and Composition Parameters on Milk Beverage Color. Thermal processing causes protein-protein interactions (Corredig and Dalgleish, 1999; Singh, 2004; Donato and Guyomarc'h, 2009) and thermal degradation of milk proteins (Van Boekel, 1998; Meltretter et al., 2007) and lactose (O'Brien, 2009), and these degradation products and interactions may influence color and viscosity of milk- 
based beverages. Caseins and milk serum proteins differ in their heat denaturation and heat-induced interaction characteristics. The effects of heat on milk proteins may influence temperature-dependent dissociation of casein and milk minerals in and out of casein micelles (Rose, 1968; Downey and Murphy, 1970), and this may influence observed color. The inclusion of these composition (fat, protein, and casein as a percent of TP) and processing (raw and pasteurized) parameters in the population of milk-based beverages in the current study will provide a robust test of the factors influencing results from the Hunter versus CIE color measurement systems at different milk testing temperatures and help determine when one or the other of the color measurement systems should be used in combination with a properly selected analysis temperature should be used for analysis of milk-based beverages.

\section{Analysis Methods}

Chemical Composition. Milk-based ingredients were analyzed in triplicate using the following analytical methods: TS were analyzed by the direct forced-air method (method number 990.20, AOAC International, 2016), fat by ether extraction (method number 989.05, AOAC International, 2016), lactose by an enzymatic method (method number 2006.06, AOAC International, 2016), total nitrogen (TN) by method number 990.20 (AOAC International, 2016), NPN by method number 990.21 (AOAC International, 2016), and noncasein nitrogen (NCN) by method number 998.05 (AOAC International, 2016). True protein was calculated as TN minus NPN multiplied by 6.38 , casein was calculated as TN minus NCN multiplied by 6.38 , and serum protein content was calculated by subtracting NPN from NCN and multiplying by 6.38 .

For monitoring, skim milk, micellar casein concentrate (MCC), and microfiltration (MF) permeate, serum protein isolate (SPI) and UF permeate composition (i.e., fat, protein, and lactose concentration, g/100 $\mathrm{g}$ of milk) during the MF and UF processing runs was analyzed using a mid-infrared (MIR) spectrophotometer (Lactoscope FTA, Delta Instruments, Drachten, the Netherlands). The MIR milk product group was calibrated using modified milk samples produced at Cornell University as described by Kaylegian et al. (2006). The reference chemistry for the calibration samples was all laboratory mean reference chemistry for the modified milk calibration samples as described by Wojciechowski et al. (2016). A milk product testing group was set up on the Delta FTA using traditional virtual filter models for fat A, fat B, TP, and anhydrous lactose measures during the run to monitor the process and ensure the processing was running properly. The wavelengths, scale factors (i.e., primary slope), and intercorrection factors for each virtual filter model were as described by Kaylegian et al. (2009).

Color. Milk protein beverages (raw and pasteurized) and commercial skim, 1 and $2 \%$ fat HTST milks were tested in duplicate using an Ultra Scan Pro Spectrophotometer (Hunter Associates Laboratory Inc., Reston, VA) at 4,20 , and $50^{\circ} \mathrm{C}$. A water bath was used to maintain sample temperature at 4,20 , or $50^{\circ} \mathrm{C}$. Milk beverages were measured in reflectance mode, wavelength from 360 to $750 \mathrm{~nm}$ with a $5 \mathrm{~nm}$ resolution, illuminant $\mathrm{A}$ at both $2^{\circ}$ and $10^{\circ}$ viewer angles. The cuvette was glass with a $20 \mathrm{~mm}$ path length. Color data were collected using both Hunter L, a, and b values and CIE $L^{*}, a^{*}$ and $b^{*}$ values.

\section{Milk-Based Ingredients}

Milk Micellar Casein Concentrate. Liquid MCC was made the day before beverage formulation; $530 \mathrm{~kg}$ of raw skim milk was obtained from North Carolina State University Dairy and HTST pasteurized (11.34 $\mathrm{kg} / \mathrm{min}$ ) using a plate heat exchanger (model T4 RGS16/2, SPX Flow Technology, Greensboro, NC) at $72^{\circ} \mathrm{C}$ with a hold time of $16 \mathrm{~s}$. The pasteurized skim milk was cooled to $4^{\circ} \mathrm{C}$, prefiltered by a Nexis T Filter (NXT 10-30U-M7S, Pall Corporation, Port Washington, NY) and stored at $4^{\circ} \mathrm{C}$ in a $1,200-\mathrm{kg}$ jacketed stainless steel tank (type A \& G, Chester-Jensen Company, Chester, PA). The pasteurized and pre-filtered skim milk was heated using a plate heat exchanger (serial no. G201400849, Plate ID: SR1, SPX Flow Technology, Greensboro, NC) to $50^{\circ} \mathrm{C}$, weighed, and poured into the MF balance tank (190 kg, NUVAT for cheese making, Meyer-Blank Company, St Louis, MO) jacketed with $50^{\circ} \mathrm{C}$ water.

A 3-stage, $3 \times$ microfiltration process described by Zulewska and Barbano (2014) was used to produce a 95\% serum-protein-removed MCC with TP concentration between 8.4 to $8.6 \%$ with the following differences in procedure. The cleaning before and after processing, clean water flux, and warm-up procedure was done as described by Zulewska et al. (2009). The MF was started by filling the flow system with deionized (DI) water and the retentate and permeate removal rates were set to 48.0 and $110 \mathrm{~L} / \mathrm{h}$, respectively, to achieve a $3 \times \mathrm{MF}$ mass/mass concentration factor, and cross-flow velocity was kept around $7.0 \mathrm{~m} / \mathrm{s}$. It is very important that all air is removed from the system on both the retentate and permeate side of the membranes. Ceramic membrane modules are mounted vertically. If there is a head space of air at the top (retentate inlet end) of the membrane module on the permeate side, then when the pumps are started permeate will flow through that area 
of the ceramic stick very fast where there is no liquid on the permeate side of the membrane providing back pressure. The will cause an immediate fouling of the membrane and a shortened processing run.

Once the switch was made to milk, MCC production began and all retentate and permeate were collected and weighed and CF was controlled based on these weights. The pasteurized and pre-filtered warm skim milk was microfiltered at $50^{\circ} \mathrm{C}$ with a MF system (Tetra Alcross MFS-7, TetraPak Filtration Systems) equipped with $0.1-\mu \mathrm{m}$ nominal pore diameter graded permeability ceramic Membralox (model EP1940GL0.1u, AGP1020, alumina, Pall Corp.) membranes (surface area of 1.68 $\mathrm{m}^{2}$, membrane length of $1.02 \mathrm{~m}$ ). The MF retentate and permeate removal rates were set to theoretical target values to achieve a $3 \times \mathrm{MF}$ mass/mass concentration factor with the retentate removal rate set to 48.0, 54.0, and $52.8 \mathrm{~L} / \mathrm{h}$ and the permeate removal rate at 110 , 120 , and $120 \mathrm{~L} / \mathrm{h}$ for stages 1,2 , and 3, respectively. The retentate recirculation pump rate was increased gradually to maintain the cross-flow velocity around $7.0 \mathrm{~m} / \mathrm{s}$ during processing. The retentate removal rate was adjusted during the run to control the concentration factor based on flux and infrared composition data every $15 \mathrm{~min}$.

The first $160 \mathrm{~kg}$ of milk taken into the MF system were used to flush water out of the system and both the retentate and permeate collected during this time were discarded. At that point the flush ended and MF stage 1 started. Next, $370 \mathrm{~kg}$ more milk at $50^{\circ} \mathrm{C}$ was used as the feed for the first stage. The second and third stages were diafiltration stages with same weight of DI water added to the retentate as permeate removed in the previous stage. The MF system was run continuously and not stopped and restarted from stage to stage as in Zulewska and Barbano (2014). The stage one $3 \times$ retentate plus DI water was heated to $50^{\circ} \mathrm{C}$ and fed into the MF for stage 2 of the process. At the beginning of stage 2 , the stage 1 retentate plus water mixture MF was recycled for $15 \mathrm{~min}$ with both the retentate and permeate going back into the feed tank. The protein concentration of MF retentate was checked using the MIR milk analyzer, and once a protein concentration of 8.4 to $8.6 \%$ was achieved, the collection of stage $2 \mathrm{MF}$ retentate and permeate started. The same diafiltration process was done for stage 3 . At the end of MF stage 3 , all retentate was mixed, cooled to $4^{\circ} \mathrm{C}$, bottled into half-gallon light shielding milk jugs (Upstate Niagara Cooperative, Buffalo, NY), and stored in $4^{\circ} \mathrm{C}$ walk-in cooler.

Serum Protein Isolate. To produce enough SPI for the study, several batches of SPI were produced and combined before the beverage study to obtain a large batch of liquid SPI. For production of each SPI batch, 1,150 or $460 \mathrm{~kg}$ of raw skim milk was obtained from the North Carolina State University Dairy. The raw skim milk was processed using the same procedure as it was in the MCC production before feeding to the MF. The MF processing of pasteurized and pre-filtered skim milk was a single-stage process with the purpose of collecting stage $1 \mathrm{MF}$ permeate with a high serum protein concentration. The stage $1 \mathrm{MF}$ permeate was collected and fed into the UF. A $50^{\circ} \mathrm{C}, 2$-stage UF process was used to produce liquid SPI with a protein concentration of about $25 \%$. Two UF membrane systems (model Pellicon 2, Millipore Inc., Billerica, MA) were set up in parallel with each one of them equipped with 5 polyethersulfone cartridge membrane filters (model P2B010V05, nominal separation cutoff $=10,000 \mathrm{kDa}$, surface area $=0.5 \mathrm{~m}^{2}$ per cartridge $)$. A variable-speed peristaltic pump (model 77410-10, Cole-Palmer, Vernon Hills, IL) equipped with 2 model 77601-00 pump heads (Cole-Palmer, Vernon Hills, IL) with silicone tubing (model 96440-73, Cole-Palmer) was used. The $1 \%$ sodium hydroxide (food grade, Sigma-Aldrich, St. Louis, MO) membrane storage solution in the UF unit was flushed out with $50^{\circ} \mathrm{C}$ DI water for $20 \mathrm{~min}$. This was done to ensure that residuals from cleaning and sanitizing compounds did not contaminate the product produced by the batch process. A UF clean water flux was taken by collecting flow from both permeate outlets for $30 \mathrm{~s}$. The UF clean water flux was 1,300 to $1,500 \mathrm{~g} / 30 \mathrm{~s}$ at $50^{\circ} \mathrm{C}$ with no back pressure. During the UF processing, about 124 to $138 \mathrm{kPa}$ back pressure was applied on the UF retentate side of the membranes. The retentate outlets were put into UF balance tank for recirculation in a batch concentration mode for each stage. The UF permeate was collected, weighed, and discarded. The UF retentate and permeate were collected to check flux and composition every $30 \mathrm{~min}$. The stopping point of UF stage 1 was defined as when the retentate protein as a percentage of lactose plus protein plus fat of UF retentate reached $41 \%$. The second stage of the UF process was a DF stage. The diafiltration water was HTST pasteurized $(11.34 \mathrm{~kg} / \mathrm{min})$ with a plate heat exchanger (model T4 RGS- 16/2, SPX Flow Technology, Greensboro, NC) at $72^{\circ} \mathrm{C}$ for $16 \mathrm{~s}$ and cooled to $50^{\circ} \mathrm{C}$. The DI water added for stage 2 was the same amount as the permeate removed in UF stage 1 . The UF stage 2 was stopped when the protein concentration in the UF retentate reached $28 \%$ measured using the MIR milk analyzer. Both retentate and permeate of UF stage 2 were collected and weighed. The SPI (i.e., second retentate) was mixed and bottled into halfgallon milk jugs and stored at $-18^{\circ} \mathrm{C}$. For cleaning after processing, the $50^{\circ} \mathrm{C}$ DI water was used to flush the UF unit for 30 min. A $50^{\circ} \mathrm{C}, 1.0 \%$ Hydroflux NP No. 366 (No. FP036601, Hydrite Chemical Co., Brookfield, WI) 
was used for alkaline cleaning and recirculated for 25 min. Next, $50^{\circ} \mathrm{C}$ DI water was used to flush the UF unit for 25 min. A $50^{\circ} \mathrm{C}, 0.5 \%$ Reflux No. 193 (manufacture no. FP019301, Hydrite Chemical Co.) was used for acid cleaning and recirculated for $20 \mathrm{~min}$. Next, $50^{\circ} \mathrm{C}$ DI water was used to flush for $20 \mathrm{~min}$. The UF unit was disassembled and the UF membranes and gaskets were stored in a $1 \%$ sodium hydroxide solution at $4^{\circ} \mathrm{C}$ until their next use. Prior to the beginning of the beverage formulation portion of the project, all the batches of frozen SPI were thawed by moving the frozen containers of SPI into a $4^{\circ} \mathrm{C}$ cooler for a 3 -d thawing. During a couple of the UF processing runs for SPI production, cleaning problems were encountered. Each SPI bottle was screened for potential microbial off-flavors by trained panelists $(\mathrm{n}=3)$, and only SPI bottles that passed the screening were mixed in cheese vat $(230 \mathrm{~kg}$, Kusel Equipment Co., Watertown, WI) and tested for protein content by MIR. The target protein content of the liquid SPI was about 25 to $28 \%$.

Cream. A cold bowl separator (model 590, Separators Inc., Indianapolis, IN) was used for raw cream separation and the pasteurized $\left(80^{\circ} \mathrm{C}\right.$ for $\left.25 \mathrm{~s}\right)$ cream containing about $41 \%$ fat was obtained from the North Carolina State University Dairy and stored at $4^{\circ} \mathrm{C}$.

Lactose and Water. Lactose monohydrate (Hilmar 5120 if Refined Edible Lactose 200 mesh, $25 \mathrm{~kg} / \mathrm{bag}$ ) was donated by Hilmar Ingredients (Hilmar Ingredients, Hilmar, CA). Potable water was processed to produce DI water using a deionizing water system (unit number: 1933-2, Mar Cor, Raleigh, NC).

\section{Beverage Formulation}

Formulations $(9,500$ g per batch) were calculated using the Microsoft Excel (Microsoft Corp., Redmond, WA) linear optimization solver function as described by Misawa et al. (2016) with the following differences. The MCC, SPI, cream, lactose and DI water were used as the raw ingredients. Within each fat level $(0.2,1$, or $2 \%$ fat), the TP and $\mathrm{CN} \% \mathrm{TP}$ were targeted at $4 \mathrm{TP}$ levels $(3.00,3.67,4.34$, and $5.00 \%)$ and 5 CN\% TP (5, $25,50,75$, and $80 \%$ ), respectively. Anhydrous lactose concentration was standardized to $4.65 \%$ for all formulations. In total, there were 20 combinations of TP and CN\%TP for each fat level in one replicate. The experiment with 20 formulations was done twice at each fat level starting with freshly produced MCC and cream. Two processing runs for skim were complete in 2 different weeks, and the same was done for the formulations within the 1 and $2 \%$ fat levels for a total of 6 different formulation and sensory sessions.

On the formulation day, MCC, SPI, cream, lactose, and DI water were kept in a $4^{\circ} \mathrm{C}$ walk-in cooler before use. Because weights of ingredients varied from one formula to the next, a 620-g maximum weight balance (model MS603TS/00, Mettler-Toledo, Greifensee, Switzerland), a 3,200-g maximum weight balance (model MS3002S/03, Mettler-Toledo), and a 32,200-g maximum weight balance (model MS32001L/03, MettlerToledo) were calibrated with standard weights (serial no. B628758127, Mettler-Toledo, Columbus, OH) to check for the accuracy and linearity of each balance. A specific balance was selected for weighing an ingredient in a formulation so that the weight of each ingredient was within the linear weight range of the balance. Translucent round food storage containers $(11.36 \mathrm{~L}$, manufacture no. FG572624, Rubbermaid, Atlanta, GA) with yellow lids (manufacture no. 1980386, Rubbermaid) were used for formulation. Beverages were formulated one by one with a specific ingredient adding order (DI water, lactose, MCC, SPI, and cream). Lactose was completely dissolved in DI water before adding other ingredients. Weights of each ingredient were recorded and checked to ensure a tolerance range of $\pm 0.1 \mathrm{~g}$ and stored at $4^{\circ} \mathrm{C}$. The MIR was used to verify the fat, lactose, and protein concentration in the milk-based beverages before and after pasteurization.

\section{Pasteurization and Homogenization}

Prior to the beginning of the first processing trial practice runs were done with the system in the same configuration as would be used in the study to determine the dead volume of the processing system and the amount of liquid that needed to run to purge water (at start up) out of the system. This was done by measuring the freezing point (Cryoscope, model no. 4250, Advanced Instruments Inc., Norwood, MA) and the fat, protein, and lactose concentration (MIR analysis) to determine how much product (and time in seconds) needed to purge through the processing system before collecting product for sensory and chemical analyses.

Within a fat level for each replicate, 9,500 $\mathrm{g}$ each of 20 raw milk beverages were well mixed individually and continuously fed to a Microthermics EHVH pasteurization unit (Microthermics, Raleigh, NC) with a 2-stage homogenizer (GEA Niro Soavi, Parma, Italy) at flow rate of $2 \mathrm{~L} / \mathrm{min}$. Each beverage formulation was preheated to $60^{\circ} \mathrm{C}$, homogenized (first stage at 17.3 $\mathrm{MPa}$ and second stage at 3.4 MPa), HTST pasteurized $\left(73^{\circ} \mathrm{C}\right.$ for $\left.15 \mathrm{~s}\right)$, and cooled to $10^{\circ} \mathrm{C}$. A timer was started when switching from water to the first beverage or from the previous beverage to the next one. Once the timer reached $4 \mathrm{~min}$, pasteurized beverage was collected into a labeled half-gallon milk jug. The end of the previous beverage collection and the switching point to the next beverage happened at $4 \mathrm{~min} 45 \mathrm{~s}$. Once a collection 
was done, the milk jug was sealed with a sanitized lid and stored in crushed ice temporarily. Pasteurized milk beverages were stored at $4^{\circ} \mathrm{C}$ after sampling.

\section{Statistical Analysis}

Milk-Based Beverages: Viewer Angle and Color Measurement System. The general linear models (GLM) procedure of SAS (version 9.4, SAS Institute Inc., Cary, NC) was used to determine the effect of viewer angle of color measurement, fat $(0.2,1$, and $2 \%)$, $\mathrm{TP}(3.0,3.67,4.34,5.0 \%), \mathrm{CN} \% \mathrm{TP}(5,25,50,75$, and $80 \%$ ), heat treatment (raw and pasteurized), measurement temperature $\left(4,20\right.$, and $\left.50^{\circ} \mathrm{C}\right)$ of color of milk protein beverages. All interactions of these parameters were included in the model. Viewer angle, fat, TP, heat treatment, and temperature were treated as categorical variables whereas $\mathrm{CN} \% \mathrm{TP}$ was handled as a continuous variable. The CN\%TP was mean-center (Misawa et al., 2016) transformed to avoid co-linearity effects on statistical analysis (Glantz and Slinker, 2001) and named as CNTPT in models. The CN\% TP was transformed by subtracting the mean $\mathrm{CN} \% \mathrm{TP}$ from each of the individual CN\% TP and using these mean-centered data in the statistical analysis to provide a better point of reference in parsing the relative strength of main effects and interaction effect of factors in the model. If the $F$-value for the full model was significant $(P<$ $0.05)$, then significance $(P<0.05)$ of each factor and their interactions was determined. The category effects of viewer angle, fat, TP, heat treatment, temperature of color measurement, replicate, and their interactions were tested for significance using the interaction term of viewer angle $\times$ fat $\times$ heat $\times$ milk true protein $($ prot $) \times$ temperature of color measurement $($ temp $) \times$ replicate (rep), whereas the effects (linear and quadratic) of the continuous variable of $\mathrm{CN} \% \mathrm{TP}$ and their interactions of the categorical variable were tested for significance using the full model error. The analysis of the color data for all factors and their interactions was done first, if the $F$-value for the full model was $<0.05$, then a stepwise process was done to remove all nonsignificant terms from the model to produce a final reduced model. The type III sum of squares table was produced and the $\mathrm{R}^{2}$ for the reduced model was reported. To better understand the relative effect of each factor or interaction of factors on each color parameter, the type III sum of squares value for each term was divided by the total type III sum of squares of the significant terms in the model to determine the relative effect of each factor and interactions of factors.

The effect of system of color measurement (Hunter vs. CIE), fat $(0.2,1$, and $2 \%)$, TP $(3.0,3.67,4.34,5.0 \%)$,
CN\%TP $(5,25,50,75$, and 80\%), heat treatment (raw and pasteurized), and measurement temperature (4, 20, and $50^{\circ} \mathrm{C}$ ) of color of milk protein beverages were determined by the same ANOVA model described above with replacing the viewer angle term with system term.

Commercial Milks with Different Fat Levels. The GLM procedure of SAS (version 9.4, SAS Institute Inc.) was used to determine the effect of color measurement system, fat level (skim, 1, and 2\%), and measurement temperature $\left(4,20\right.$, and $\left.50^{\circ} \mathrm{C}\right)$ of color of commercial HTST pasteurized milks. All interactions of these parameters were included in the model. Color measurement system, fat, and temperature were treated as categorical variables. The same stepwise process was done as described previously to produce a final reduced model and a type III sum of squares table. The $\mathrm{R}^{2}$ for the reduced model was reported. The type III sum of squares value for each term was divided by the total type III sum of squares of the significant terms in the model to clarify the relative effect of each factor and interactions of factors. Additionally, a similar GLM procedure was applied on milk color data within each fat level and within each color measurement system to determine the effect of measurement temperature, using the LSMEANS procedure of GLM if the $F$-value for the model had a $P<0.05$.

\section{RESULTS AND DISCUSSION}

\section{Evaluation of Methods of Color Measurement}

Viewer Angle. The Hunter L, a, and b values and CIE $a^{*}, b^{*}$, and $L^{*}$ values for a wide range of milkbased beverage compositions for a viewer angle of $10^{\circ}$ and $2^{\circ}$ are shown in Table 2. Most of the variation in instrumental measurement of color for the beverages in this study was explained by variation in fat, CN\% TP, and thermal treatment of the beverages (Table 3). The variation in CN\%TP (5 to $80 \%$ of TP) had a much larger (Table 3) effect on color than variation in TP (3 to $5 \%$ ). Variation in fat had a larger effect on a and b values than on $\mathrm{L}$-value, whereas variation in $\mathrm{CN} \% \mathrm{TP}$ had much large effect on L-value than fat for the combination of raw and pasteurized beverages. The effect of component variation and processing on instrumental and sensory measures of color will be discussed in more detail in a separate paper.

No significant effects $(P>0.05)$ of viewer angle or interactions of viewer angle $\left(10\right.$ vs. $\left.2^{\circ}\right)$ were detected on either the Hunter L-value or CIE L*-value measurements (Table 3). Only a small effect was observed of viewer angle (terms for angle and CNTPT $\times$ viewer angle) on the Hunter a and b-values and the CIE a* 


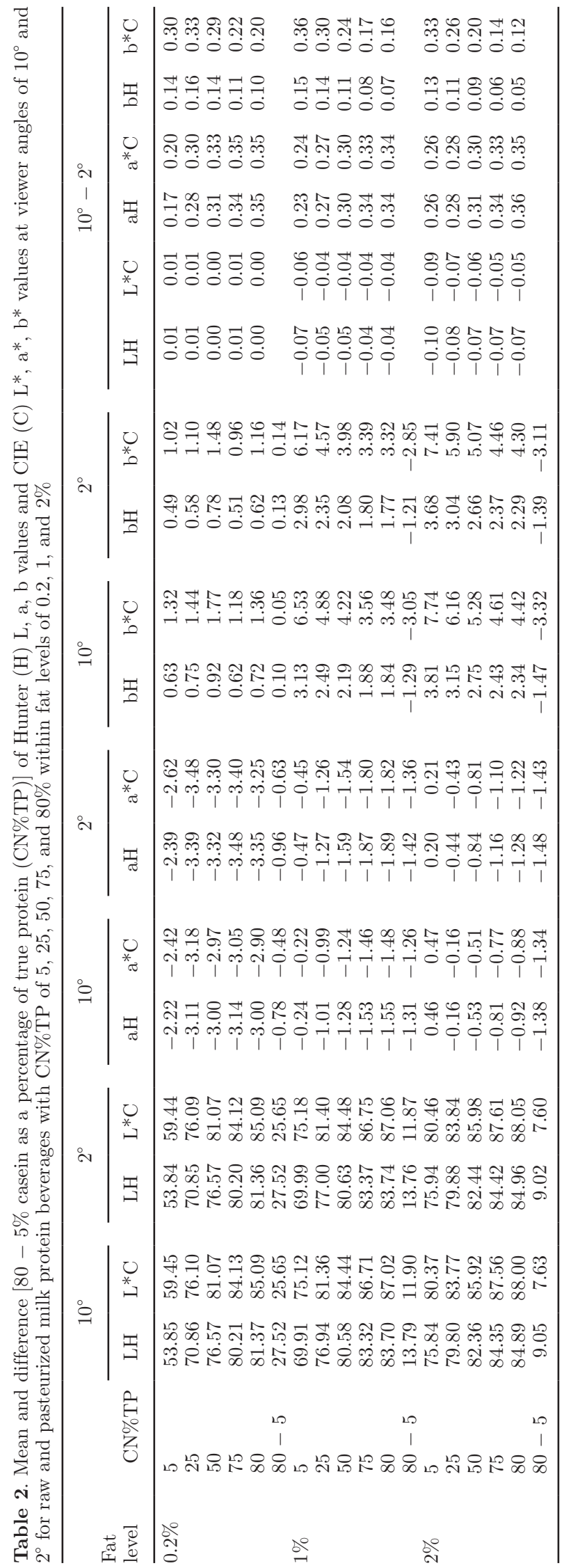

and $\mathrm{b}^{*}$-values. In the current study, the viewer angle explained less than $3 \%$ of the total type III sum of squares variation (Table 3) in results for a wide range of milk-based beverage composition. No significant effects $(P>0.05)$ of any other interaction terms with viewer angle were detected (Table 3). Therefore, in subsequent analyses to determine the effect of color measurement system, only data from a viewer angle of $10^{\circ}$ was used.

Hunter Versus CIE Color Measurement. Data for both color measurement systems at a viewer angle of $10^{\circ}$ for raw and pasteurized milk-based beverages ranging from 0.2 to $2 \%$ fat, 3 to $5 \%$ protein, and 5 to $80 \%$ CN\% TP are shown in Table 2. The relative proportion of variation explained by color measurement system and other beverage composition factors, thermal processing conditions, and temperature at which color was measured for a viewer angle of $10^{\circ}$ is shown in Table 4.

$L / L^{*}$ Values. Choice of color measurement system explained about $7.17 \%$ of the total variation in $\mathrm{L} / \mathrm{L}^{*}$ value measurement (Table 4) with CIE system reporting higher L-values (Table 2) than the Hunter system. However, the interactions of measurement system with other factors in the model were mostly not significant $(P>0.05)$ or only explained a very small percentage (e.g., system $\times$ fat, system $\times$ heat, and so on) of the variation (Table 4). The Hunter L-value was more sensitive than CIE $\mathrm{L}^{*}$-value to differences in whiteness among beverages differing in CN\%TP at all 3 fat levels as shown by the larger differences between to 80 and $5 \%$ CN\% TP levels (Table 2). Thus, the difference between Hunter and CIE measures of whiteness (L-value) are primarily a bias difference with the CIE system yielding higher values for whiteness than Hunter when fat (Figure 1), CN\%TP (Figure 2), and TP (Figure 3) concentrations vary in milk-based beverages.

$a / a^{*}$ Values. Color measurement system only explained a small percentage $(0.01 \%)$ of the total variation in a/a* (Table 4) with CIE and Hunter systems producing similar a/a* values (Table 2 ). Interaction of color measurement system with other factors in the model was mostly not significant $(P>0.05)$ or only explained a very small percentage (system $\times$ fat $\times$ heat, $\mathrm{CNTPT} \times$ system $\times$ fat, $\mathrm{CNTPT} \times$ system $\times$ heat $)$ of the variation (Table 4). Therefore, CIE and Hunter systems differed very little in redness-greenness $\left(\mathrm{a} / \mathrm{a}^{*}\right.$ values) measurements of milk protein beverages in the present study.

$\boldsymbol{b} / \boldsymbol{b}^{*}$ Values. System alone explained $14.84 \%$ of the total variation in $\mathrm{b} / \mathrm{b}^{*}$ values (Table 4 ) with Hunter system indicating lower b-values (Table 2) than the CIE system. Interactions of system and other terms in the models were all significant for $\mathrm{b} / \mathrm{b}^{*}$ values (Table 
Table 3. Percentage of type III sum of squares variation explained by model factors $($ angle $=$ viewer angle, fat $=$ fat level, heat $=$ pasteurization and homogenization, prot $=$ milk true protein, temp $=$ temperature of color measurement, rep $=$ replicate, and $\mathrm{CNTPT}=$ casein as a percentage of true protein transformed) for Hunter L, a, b and CIE L*, a*, and $\mathrm{b}^{*}$ values for milk protein beverages

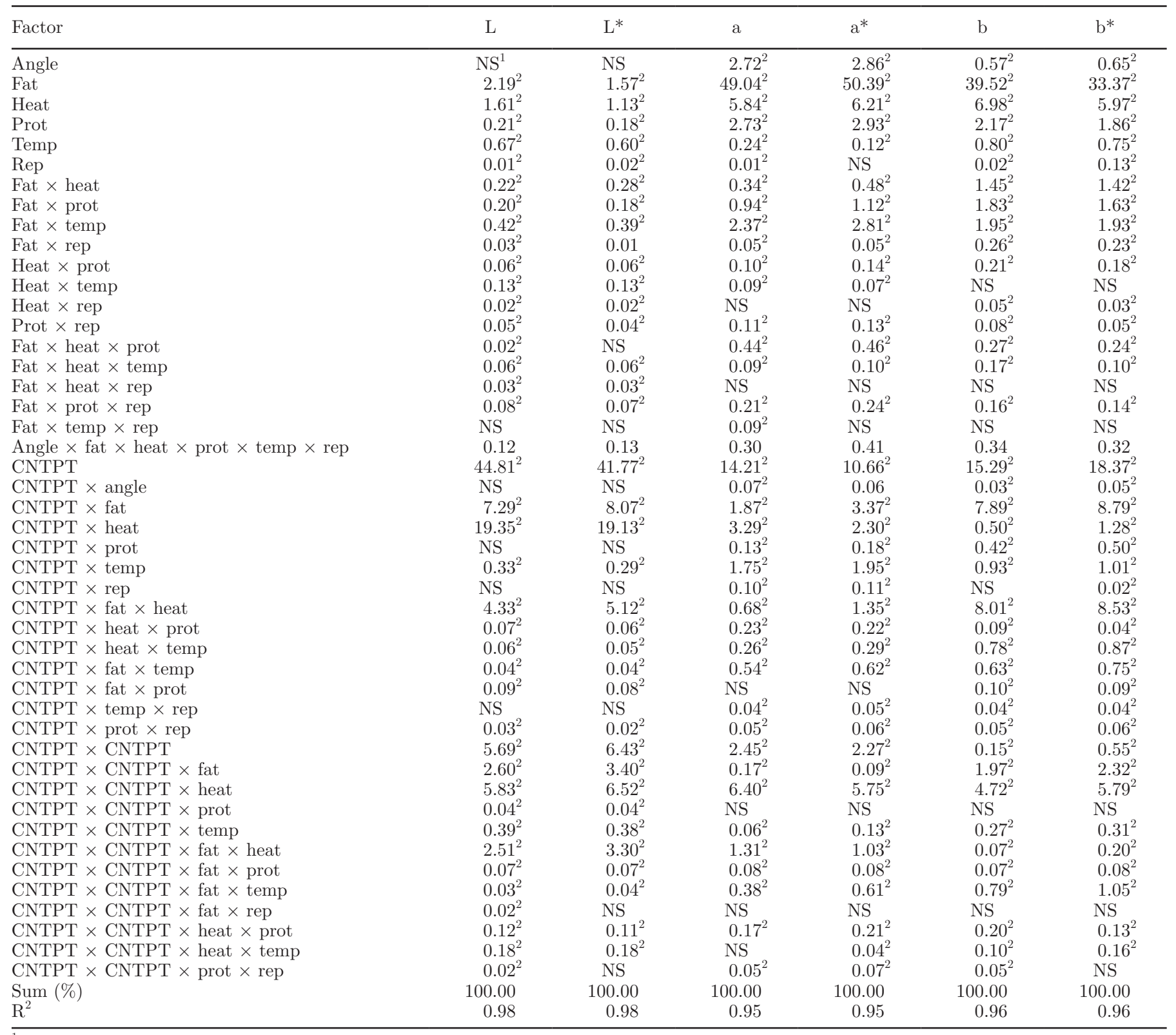

${ }^{1} \mathrm{NS}$ : means $P>0.05$.

${ }^{2}$ Means $P<0.05$.

4). System $\times$ fat, CNTPT $\times$ system, and CNTPT $\times$ system $\times$ fat counted for $2.68,2.26$, and $0.89 \%$ of the total variation in $\mathrm{b} / \mathrm{b}^{*}$ values, respectively, while all the other system involved interactions explained $3.73 \%$ of the total variation in $\mathrm{b} / \mathrm{b}^{*}$ values with each one counted less than $0.75 \%$ (Table 4 ). The Hunter system is less sensitive in measuring differences in yellowness of milk-based beverages than the CIE system as fat content (Figure 4) and as CN\%TP content (Figure 5) change (CIE, 1978; Hunter and Harold, 1987; Hunter Associates Laboratory, 2012).

\section{Objective Color Measures for Commercial Skim, 1\% and 2\% Fat Fluid Milks}

Data for Hunter and CIE color measurement systems at a viewer angle of $10^{\circ}$ for commercial HTST pasteurized milks from skim to $2 \%$ fat and 4 to $50^{\circ} \mathrm{C}$ 
Table 4. Percentage of type III sum of squares variation explained by model factors (system $=$ color system, fat $=$ fat level, heat $=$ pasteurization and homogenization, prot $=$ milk true protein, temp $=$ temperature of color measurement, rep $=$ replicate, and $\mathrm{CNTPT}=$ casein as a percentage of true protein transformed) for $\mathrm{L} / \mathrm{L}^{*}, \mathrm{a} / \mathrm{a}^{*}$, and $\mathrm{b} / \mathrm{b}^{*}$ values (Hunter, CIE) for milk protein beverages at a $10^{\circ}$ viewer angle

\begin{tabular}{|c|c|c|c|}
\hline Factor & L10 & a10 & b10 \\
\hline System & $7.17^{1}$ & $0.01^{1}$ & $14.84^{1}$ \\
\hline Fat & $1.71^{1}$ & $52.54^{1}$ & $25.60^{1}$ \\
\hline Heat & $1.27^{1}$ & $5.74^{1}$ & $4.72^{1}$ \\
\hline Prot & $0.18^{1}$ & $2.85^{1}$ & $1.51^{1}$ \\
\hline Temp & $0.59^{1}$ & $0.18^{1}$ & $0.60^{1}$ \\
\hline Rep & $0.01^{1}$ & $\mathrm{NS}^{2}$ & $0.10^{1}$ \\
\hline Fat $\times$ heat & $0.23^{1}$ & $0.44^{1}$ & $1.07^{1}$ \\
\hline Fat $\times$ prot & $0.17^{1}$ & $1.11^{1}$ & $1.26^{1}$ \\
\hline Fat $\times$ temp & $0.37^{1}$ & $2.73^{1}$ & $1.42^{1}$ \\
\hline Fat $\times$ rep & $0.03^{1}$ & $0.06^{1}$ & $0.18^{1}$ \\
\hline Heat $\times$ prot & $0.05^{1}$ & $0.14^{1}$ & $0.14^{1}$ \\
\hline Heat $\times$ temp & $0.12^{1}$ & $0.05^{1}$ & NS \\
\hline Heat $\times$ rep & $0.02^{1}$ & NS & NS \\
\hline Prot $\times$ rep & $0.04^{1}$ & $0.12^{1}$ & $0.04^{1}$ \\
\hline Temp $\times$ rep & 0.01 & NS & NS \\
\hline System $\times$ fat & $0.06^{1}$ & NS & $2.68^{1}$ \\
\hline System $\times$ heat & $0.11^{1}$ & NS & $0.51^{1}$ \\
\hline System $\times$ prot & NS & NS & $0.46^{1}$ \\
\hline System $\times$ temp & NS & NS & $0.07^{1}$ \\
\hline Fat $\times$ heat $x$ prot & NS & $0.46^{1}$ & $0.19^{1}$ \\
\hline Fat $\times$ heat $\times$ temp & $0.06^{1}$ & $0.10^{1}$ & $0.08^{1}$ \\
\hline Fat $\times$ heat $\times$ rep & $0.03^{1}$ & NS & $0.11^{1}$ \\
\hline Fat $\times$ prot $\times$ rep & $0.07^{1}$ & $0.23^{1}$ & NS \\
\hline Fat $\times$ temp $\times$ rep & NS & $0.09^{1}$ & NS \\
\hline System $\times$ fat $\times$ heat & NS & $0.08^{1}$ & $0.64^{1}$ \\
\hline System $\times$ fat $\times$ prot & NS & NS & $0.26^{1}$ \\
\hline System $\times$ fat $\times$ temp & NS & NS & $0.06^{1}$ \\
\hline System $\times$ heat $\times$ temp & NS & NS & $0.04^{1}$ \\
\hline System $\times$ fat $\times$ heat $\times$ prot $\times$ temp $\times$ rep & 0.14 & 0.27 & 0.38 \\
\hline 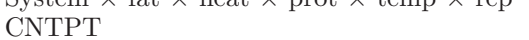 & $40.13^{1}$ & $11.69^{1}$ & $14.80^{1}$ \\
\hline CNTPT $\times$ system & $0.20^{1}$ & $0.09^{1}$ & $2.26^{1}$ \\
\hline CNTPT $\times$ fat & $7.06^{1}$ & $2.83^{1}$ & $6.47^{1}$ \\
\hline CNTPT $\times$ heat & $17.81^{1}$ & $2.88^{1}$ & $0.77^{1}$ \\
\hline CNTPT $\times$ prot & NS & $0.17^{1}$ & $0.37^{1}$ \\
\hline CNTPT $\times$ temp & $0.28^{1}$ & $1.87^{1}$ & $0.81^{1}$ \\
\hline CNTPT $\times$ rep & NS & $0.10^{1}$ & NS \\
\hline $\mathrm{CNTPT} \times$ system $\times$ fat & $0.06^{1}$ & $0.07^{1}$ & $0.89^{1}$ \\
\hline CNTPT $\times$ system $\times$ heat & NS & $0.03^{1}$ & $0.27^{1}$ \\
\hline CNTPT $\times$ system $\times$ prot & NS & NS & $0.06^{1}$ \\
\hline CNTPT $\times$ system $\times$ temp & NS & NS & $0.11^{1}$ \\
\hline CNTPT $\times$ fat $\times$ heat & $4.33^{1}$ & $1.17^{1}$ & $6.39^{1}$ \\
\hline CNTPT $\times$ heat $\times$ prot & $0.06^{1}$ & $0.23^{1}$ & $0.04^{1}$ \\
\hline CNTPT $\times$ heat $\times$ temp & $0.05^{1}$ & $0.29^{1}$ & $0.63^{1}$ \\
\hline CNTPT $\times$ fat $\times$ temp & $0.03^{1}$ & $0.61^{1}$ & $0.54^{1}$ \\
\hline CNTPT $\times$ fat $\times$ prot & $0.08^{1}$ & NS & $0.07^{1}$ \\
\hline CNTPT $\times$ temp $\times$ rep & NS & $0.04^{1}$ & NS \\
\hline CNTPT $\times$ prot $\times$ rep & $0.02^{1}$ & $0.06^{1}$ & $0.07^{1}$ \\
\hline $\mathrm{CNTPT} \times \mathrm{CNTPT}$ & $5.59^{1}$ & $2.40^{1}$ & $0.27^{1}$ \\
\hline $\mathrm{CNTPT} \times \mathrm{CNTPT} \times$ system & NS & NS & $0.10^{1}$ \\
\hline CNTPT $\times$ CNTPT $\times$ fat & $2.73^{1}$ & $0.10^{1}$ & $1.74^{1}$ \\
\hline CNTPT $\times$ CNTPT $\times$ heat & $5.70^{1}$ & $6.04^{1}$ & $4.05^{1}$ \\
\hline CNTPT $\times$ CNTPT $\times$ prot & $0.03^{1}$ & NS & NS \\
\hline CNTPT $\times$ CNTPT $\times$ temp & $0.35^{1}$ & $0.10^{1}$ & $0.22^{1}$ \\
\hline CNTPT $\times$ CNTPT $\times$ system $\times$ fat & NS & NS & $0.23^{1}$ \\
\hline $\mathrm{CNTPT} \times \mathrm{CNTPT} \times$ system $\times$ heat & NS & NS & $0.71^{1}$ \\
\hline $\mathrm{CNTPT} \times \mathrm{CNTPT} \times$ system $\times$ temp & NS & NS & $0.03^{1}$ \\
\hline $\mathrm{CNTPT} \times \mathrm{CNTPT} \times$ fat $\times$ heat & $2.65^{1}$ & $1.11^{1}$ & $0.13^{1}$ \\
\hline CNTPT $\times$ CNTPT $\times$ fat $\times$ prot & $0.06^{1}$ & $0.08^{1}$ & $0.06^{1}$ \\
\hline CNTPT $\times$ CNTPT $\times$ fat $\times$ temp & $0.03^{1}$ & $0.53^{1}$ & $0.72^{1}$ \\
\hline $\mathrm{CNTPT} \times \mathrm{CNTPT} \times$ fat $\times$ rep & $0.02^{1}$ & NS & NS \\
\hline CNTPT $\times$ CNTPT $\times$ heat $\times$ prot & $0.11^{1}$ & $0.19^{1}$ & $0.11^{1}$ \\
\hline CNTPT $\times$ CNTPT $\times$ heat $\times$ temp & $0.16^{1}$ & 0.03 & $0.11^{1}$ \\
\hline CNTPT $\times$ CNTPT $\times$ prot $\times$ rep & $0.01^{1}$ & $0.06^{1}$ & NS \\
\hline Sum $(\%)$ & 100.00 & 100.00 & 100.00 \\
\hline $\mathrm{R}^{2}$ & 0.98 & 0.95 & 0.96 \\
\hline
\end{tabular}

${ }^{1}$ Means $P<0.05$

${ }^{2} \mathrm{NS}$, means $P>0.05$. 


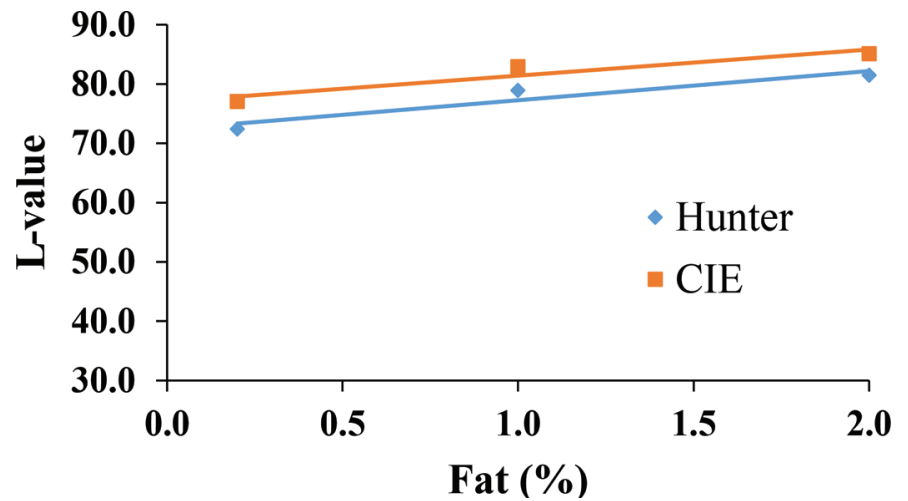

Figure 1. The L-values for milk protein beverages with CIE and Hunter color measurement systems as a function of fat percent at a $10^{\circ}$ viewer angle. $\mathrm{n}=120$ per each fat level for a total of 360 for each color measurement method and 720 treatments for the full experiment. Each treatment sample was tested in duplicate. CIE = International Commission on Illumination. Color version available online.

are shown in Table 5 . The relative proportion of variation explained by color measurement system, fat, and temperature at which color was measured for a viewer angle of $10^{\circ}$ is shown in Table 6.

$\boldsymbol{L} / \boldsymbol{L}^{*}$ Values. Color measurement system explained about $29.77 \%$ of the total variation in $\mathrm{L} / \mathrm{L}^{*}$ value measurement (Table 6) for commercial skim, 1 and $2 \%$ fat milks versus $7.17 \%$ of total variation (Table 4 ) for beverages that vary in CN\%TP. The CIE system reported higher L-values (Table 5) than the Hunter system. But the interactions of system with other factors in the model were mostly not significant $(P>0.05)$ or only explained a very small percentage (system $\times$ fat, system $\times$ temp, system $\times$ fat $\times$ temp and system $\times$ fat $\times$ rep) of the variation (Table 6 ). Therefore, the difference be-

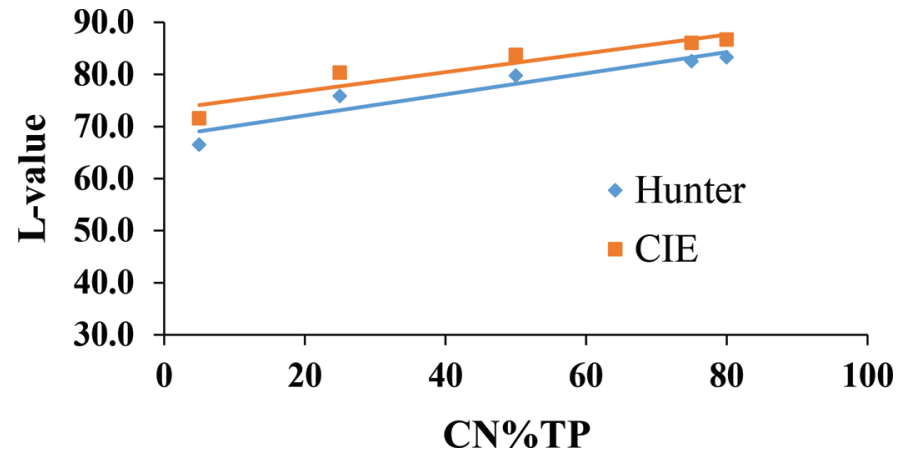

Figure 2. The L-values for milk protein beverages with International Commission on Illumination (CIE) and Hunter color measurement systems as a function of casein as a percentage of true protein $(\mathrm{CN} \% \mathrm{TP})$ at a $10^{\circ}$ viewer angle. $\mathrm{n}=72$ at each CN\% TP level for a total of 360 for each color measurement method and 720 treatments for the full experiment. Each treatment sample was tested in duplicate. Color version available online.

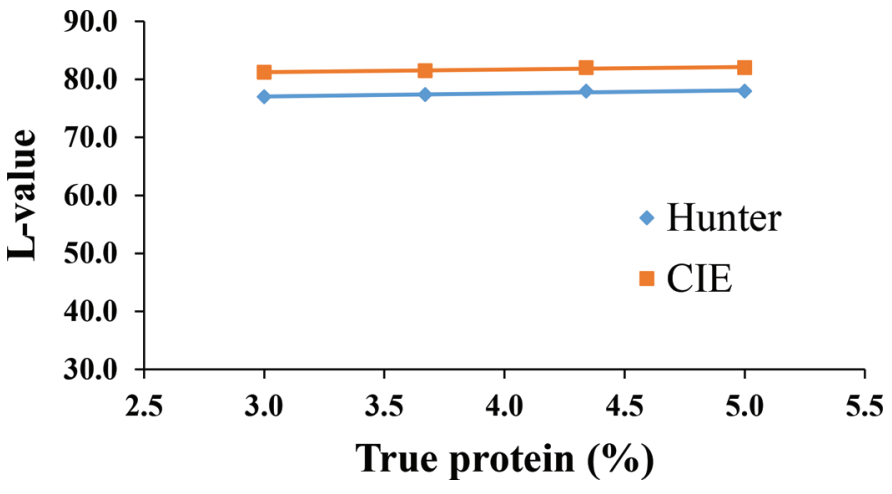

Figure 3. The L-values for milk protein beverages with International Commission on Illumination (CIE) and Hunter color measurement systems as a function of true protein percent at a $10^{\circ}$ viewer angle. $\mathrm{n}=90$ at each true protein level for a total of 360 for each color measurement method and 720 treatments for the full experiment. Each treatment sample was tested in duplicate. Color version available online.

tween Hunter and CIE measures of whiteness (L-value) is primarily a bias difference with the CIE system yielding higher values for whiteness than Hunter when fat (Figure 6) and milk measurement temperature (Figure 7) vary among in commercial HTST pasteurized milks.

$\boldsymbol{a} / \boldsymbol{a}^{*}$ Values. Color measurement system only explained a small percentage $(0.05 \%)$ of the total variation in a/a* (Table 6) with CIE and Hunter systems producing similar a/a* values (Table 5 ). Interaction of color measurement system with other factors in the model were mostly not significant $(P>0.05)$ or only explained a very small percentage (system $\times$ fat, system $\times$ temp, system $\times$ fat $\times$ temp and system $\times$ fat $\times$ rep) of the variation (Table 6 ). The CIE and Hunter systems differed very little in redness-greenness $\left(\mathrm{a} / \mathrm{a}^{*}\right.$

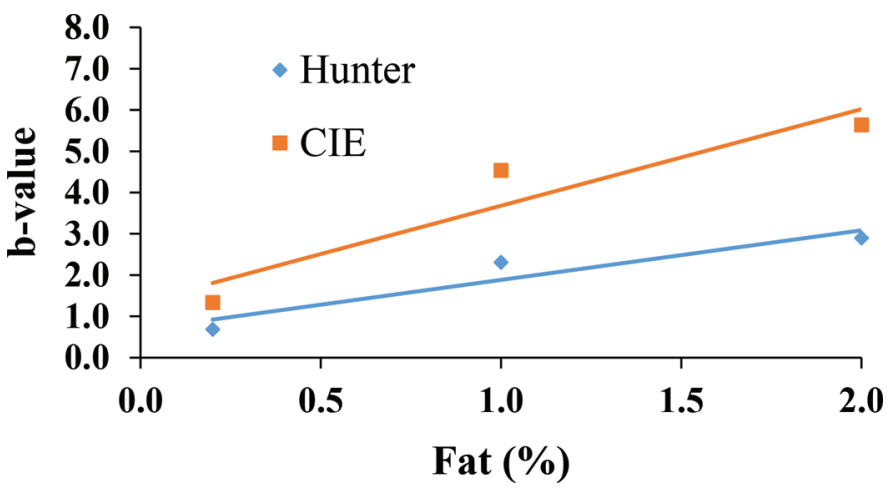

Figure 4. The b-values for milk protein beverages with International Commission on Illumination (CIE) and Hunter color measurement systems as a function of fat percent at a $10^{\circ}$ viewer angle. $\mathrm{n}=120$ at each fat level for a total of 360 for each color measurement method and 720 treatments for the full experiment. Each treatment sample was tested in duplicate. Color version available online. 
Table 5. Mean of Hunter (H) L, a, b values and CIE (C) L*, $a^{*}, b^{*}$ values for commercial HTST pasteurized skim, 1 and $2 \%$ fat milks with a temperature of 4,20 , and $50^{\circ} \mathrm{C}$ at a $10^{\circ}$ viewer angle

\begin{tabular}{|c|c|c|c|c|c|c|c|}
\hline $\begin{array}{l}\text { Fat } \\
\text { level }\end{array}$ & $\begin{array}{l}\text { Temperature } \\
\left({ }^{\circ} \mathrm{C}\right)\end{array}$ & LH10 & $\mathrm{L}^{*} \mathrm{C} 10$ & $\mathrm{aH} 10$ & $\mathrm{a}^{*} \mathrm{C} 10$ & bH10 & $\mathrm{b}^{*} \mathrm{C} 10$ \\
\hline Skim & 4 & $76.91^{\mathrm{c}}$ & $81.38^{\mathrm{c}}$ & $-4.26^{\mathrm{c}}$ & $-4.21^{\mathrm{c}}$ & $1.93^{\mathrm{b}}$ & $3.76^{\mathrm{b}}$ \\
\hline Skim & 20 & $79.83^{\mathrm{b}}$ & $83.82^{\mathrm{b}}$ & $-3.59^{\mathrm{b}}$ & $-3.50^{\mathrm{b}}$ & $2.31^{\mathrm{a}}$ & $4.45^{\mathrm{a}}$ \\
\hline Skim & 50 & $82.36^{\mathrm{a}}$ & $85.92^{\mathrm{a}}$ & $-3.06^{\mathrm{a}}$ & $-2.94^{\mathrm{a}}$ & $2.36^{\mathrm{a}}$ & $4.51^{\mathrm{a}}$ \\
\hline $\mathrm{SE}^{1}$ & & 0.111 & 0.094 & 0.006 & 0.007 & 0.039 & 0.019 \\
\hline Skim & $50-4$ & 5.44 & 4.54 & 1.21 & 1.27 & 0.43 & 0.75 \\
\hline $1 \%$ fat & 4 & $83.39^{\mathrm{c}}$ & $86.77^{\mathrm{c}}$ & $-1.20^{\mathrm{a}}$ & $-1.15^{\mathrm{a}}$ & $3.80^{\mathrm{a}}$ & $7.35^{\mathrm{a}}$ \\
\hline $1 \%$ fat & 20 & $83.77^{\mathrm{b}}$ & $87.08^{\mathrm{b}}$ & $-1.46^{\mathrm{b}}$ & $-1.40^{\mathrm{b}}$ & $3.55^{\mathrm{b}}$ & $6.84^{\mathrm{b}}$ \\
\hline $1 \%$ fat & 50 & $84.49^{\mathrm{a}}$ & $87.67^{\mathrm{a}}$ & $-1.53^{\mathrm{b}}$ & $-1.46^{\mathrm{b}}$ & $3.27^{\mathrm{c}}$ & $6.24^{\mathrm{c}}$ \\
\hline $\mathrm{SE}$ & & 0.082 & 0.068 & 0.082 & 0.025 & 0.017 & 0.032 \\
\hline $1 \%$ fat & $50-4$ & 1.10 & 0.90 & -0.33 & -0.31 & -0.54 & -1.11 \\
\hline $2 \%$ fat & 4 & $85.92^{\mathrm{a}}$ & $88.84^{\mathrm{a}}$ & $-0.30^{\mathrm{a}}$ & $-0.28^{\mathrm{a}}$ & $4.02^{\mathrm{a}}$ & $7.71^{\mathrm{a}}$ \\
\hline $2 \%$ fat & 20 & $85.51^{\mathrm{b}}$ & $88.50^{\mathrm{b}}$ & $-0.53^{\mathrm{b}}$ & $-0.50^{\mathrm{b}}$ & $3.84^{\mathrm{b}}$ & $7.36^{\mathrm{b}}$ \\
\hline $2 \%$ fat & 50 & $85.80^{\mathrm{a}}$ & $88.74^{\mathrm{a}}$ & $-0.73^{\mathrm{c}}$ & $-0.69^{\mathrm{c}}$ & $3.59^{\mathrm{c}}$ & $6.86^{\mathrm{c}}$ \\
\hline SE & & 0.085 & 0.070 & 0.023 & 0.022 & 0.019 & 0.039 \\
\hline $2 \%$ fat & $50-4$ & -0.12 & -0.10 & -0.43 & -0.41 & -0.43 & -0.86 \\
\hline
\end{tabular}

${ }^{a-c}$ Means within the same column and the same fat level that do not share a common superscript differ $(P<$ $0.05)$.

values) measurements of commercial HTST pasteurized milks.

$\boldsymbol{b} / \boldsymbol{b}^{*}$ Values. System alone explained $62.91 \%$ of the total variation in $\mathrm{b} / \mathrm{b}^{*}$ values (Table 6) with CIE system reporting higher b-values (Table 5) than the Hunter system. Interactions of system and other terms in the models were all significant for $\mathrm{b} / \mathrm{b}^{*}$ values (Table 6 ). System $\times$ fat explained $2.97 \%$ of the total variation in $\mathrm{b} / \mathrm{b}^{*}$ values, whereas all the other system involved interactions only explained $0.32 \%$ of the total variation in $\mathrm{b} / \mathrm{b}^{*}$ values (Table 6 ). The CIE system is more sensitive to measuring differences in yellowness of commercial HTST pasteurized milks than the Hunter system as fat level (Figure 8) changes.

Table 6. Percentage of variation explained by model factors (system $=$ color system, fat $=$ fat level, temp $=$ temperature of color measurement, and rep $=$ replicate) for $\mathrm{L} / \mathrm{L}^{*}, \mathrm{a} / \mathrm{a}^{*}$, and $\mathrm{b} / \mathrm{b}^{*}$ values [Hunter, International Commission on Illumination (CIE)] for commercial HTST pasteurized milks at a $10^{\circ}$ viewer angle

\begin{tabular}{lccc}
\hline Factor & L10 & a10 & b10 \\
\hline System & $29.77^{1}$ & $0.05^{1}$ & $62.91^{1}$ \\
Fat & $54.28^{1}$ & $94.01^{1}$ & $30.75^{1}$ \\
Temp & $6.55^{1}$ & $0.26^{1}$ & $0.49^{1}$ \\
Rep & $0.01^{1}$ & $0.04^{1}$ & $\mathrm{NS}^{2}$ \\
System $\times$ fat & $0.49^{1}$ & $0.01^{1}$ & $2.97^{1}$ \\
System $\times$ temp & $0.06^{1}$ & $\mathrm{NS}$ & $0.07^{1}$ \\
Fat $\times$ temp & $8.27^{1}$ & $5.41^{1}$ & $1.98^{1}$ \\
Fat $\times$ rep & $0.31^{1}$ & $0.18^{1}$ & $0.55^{1}$ \\
Temp $\times$ rep & $0.19^{1}$ & $0.02^{1}$ & $0.01^{1}$ \\
System $\times$ fat $\times$ temp & $0.07^{1}$ & $\mathrm{NS}$ & $0.19^{1}$ \\
System $\times$ fat $\times$ rep & $\mathrm{NS}$ & $\mathrm{NS}$ & $0.06^{1}$ \\
Fat $\times$ temp $\times$ rep & $0.01^{1}$ & $0.02^{1}$ & $0.03^{1}$ \\
Sum $\%)$ & 100.00 & 100.00 & 100.00 \\
$\mathrm{R}^{2}$ & 1.00 & 1.00 & 1.00 \\
\hline
\end{tabular}

${ }^{1}$ Means $P<0.05$.

${ }^{2}$ NS: means $P>0.05$.

\section{Sensitivity of Color Measurement to Milk Temperature}

$\boldsymbol{L} / \boldsymbol{L}^{*}$ Values. Temperature contributed to about $6.55 \%$ of the total variation of $\mathrm{L} / \mathrm{L}^{*}$ values (Table 6) with $50^{\circ} \mathrm{C}$ skim milk having higher $(P<0.05)$ $\mathrm{L} / \mathrm{L}^{*}$ values than $4^{\circ} \mathrm{C}$ skim milk, respectively (76.91 versus 82.36 and 81.38 versus 85.92 for Hunter and CIE, respectively). All temperature-related interaction terms in the model were significant for $\mathrm{L} / \mathrm{L}^{*}$ values with fat $\times$ temp accounting for $8.27 \%$ of the total variance (Table 6). Increasing temperature of color measurement from 4 to $50^{\circ} \mathrm{C}$ increased $\mathrm{L} / \mathrm{L}^{*}$ values less (i.e., lower slope, Figure 9) as fat level increased in commercial HTST pasteurized milks. The large decrease in

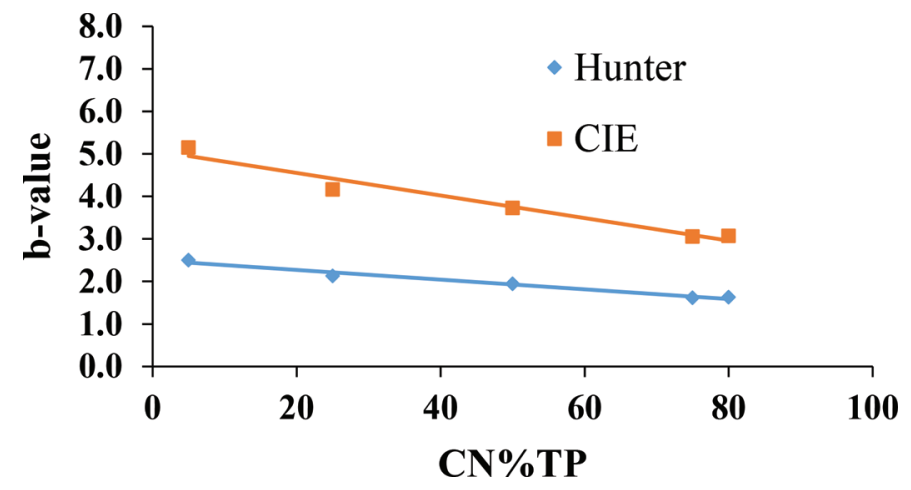

Figure 5. The b-values for milk protein beverages with International Commission on Illumination (CIE) and Hunter color measurement systems as a function of casein as a percentage of true protein $(\mathrm{CN} \% \mathrm{TP})$ at a $10^{\circ}$ viewer angle. $\mathrm{n}=72$ at each CN\% TP level for a total of 360 for each color measurement method and 720 treatments for the full experiment. Each treatment sample was tested in duplicate. Color version available online. 


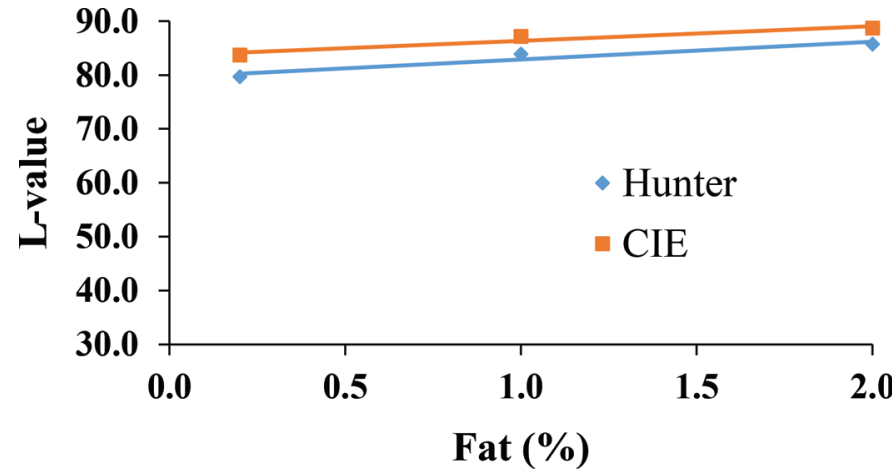

Figure 6. The L-values for commercial HTST pasteurized milks with International Commission on Illumination (CIE) and Hunter color measurement systems as a function of fat percent at a $10^{\circ}$ viewer angle. $\mathrm{n}=3$ at each fat level for a total of 9 for each color measurement method and 18 treatments for the full experiment. Each treatment sample was tested in duplicate. Color version available online.

whiteness of skim milk with decreasing color measurement temperature (Figure 9) was probably due to low temperature-induced migration of monomeric casein and calcium phosphate out of the casein micelles into the milk serum phase (Rose, 1968; Downey and Murphy, 1970) and a reduction of light scattering by the changed casein micelles at 4 versus $50^{\circ} \mathrm{C}$. This change in the casein micelles happens in the milk containing 1 and $2 \%$ fat with change in milk temperature, but there was a smaller effect of measurement temperature on the L-value of 1 and $2 \%$ milk than skim milk. This was because the fat globules are larger than casein micelles and the fat globules are reflecting most of the light at all 3 temperatures. Although the fat within fat globules at 4 versus $50^{\circ} \mathrm{C}$ was probably very different with respect to the proportion of liquid versus solid fat

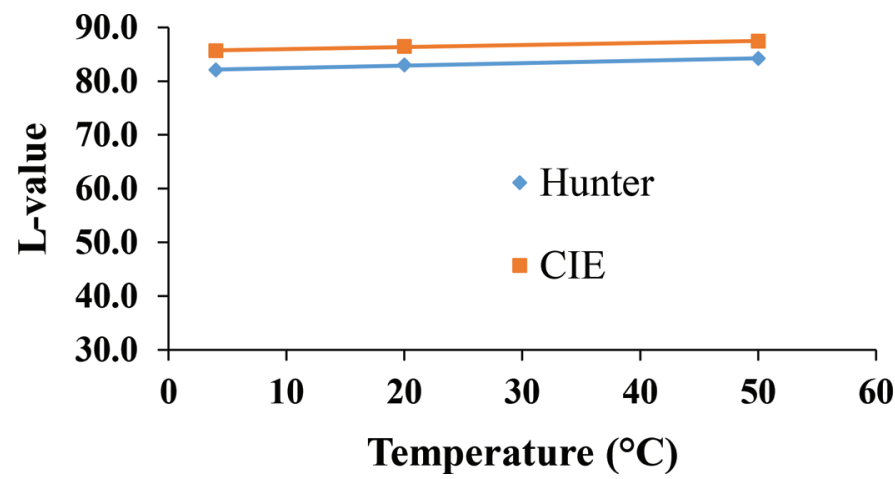

Figure 7. The L-values for commercial HTST pasteurized milks with International Commission on Illumination (CIE) and Hunter color measurement systems as a function of temperature at a $10^{\circ}$ viewer angle. $\mathrm{n}=3$ at each fat level for a total of 9 for each color measurement method and 18 for the full experiment. Each treatment sample was tested in duplicate. Color version available online.

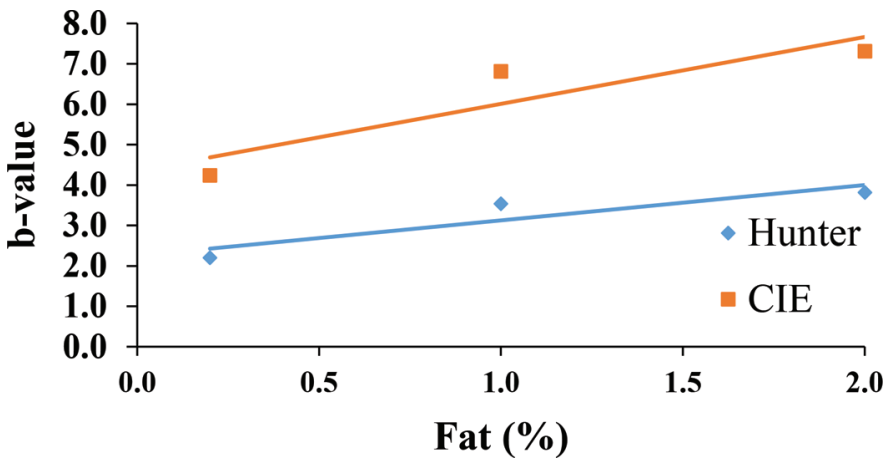

Figure 8. The b-values for commercial HTST pasteurized milks with International Commission on Illumination (CIE) and Hunter color measurement systems as a function of fat percent at a $10^{\circ}$ viewer angle. $\mathrm{n}=3$ at each fat level for a total of 9 for each color measurement method and 18 treatments for the full experiment. Each treatment sample was tested in duplicate. Color version available online.

within the fat droplets, this did not have an effect on the reflection of all wavelengths of light.

$a / a^{*}$ Values. About $0.26 \%$ of the total variation of $a / a^{*}$ values was explained by temperature (Table 6) with $50^{\circ} \mathrm{C}$ skim milk having higher a/a* values than $4^{\circ} \mathrm{C}$ skim milk $(P<0.05)$, whereas $50^{\circ} \mathrm{C} 1 \%$ and $2 \%$ fat milks had lower $(P<0.05)$ a/a* values than $4^{\circ} \mathrm{C}$ (Table 5). The fat $\times$ temp interaction explained $5.41 \%$ of the total variation of $\mathrm{a} / \mathrm{a}^{*}$ values with respect to color measurement temperature (Table 6 and Figure 10). Increasing color measurement temperature increased a/a* values at lower fat levels commercial HTST milks, whereas a/a* values decreased in higher fat milks (i.e., crossing of the linear regression lines in Figure 10). If more fat levels (i.e., >3) were tested, then it would probably become more clear that as fat level

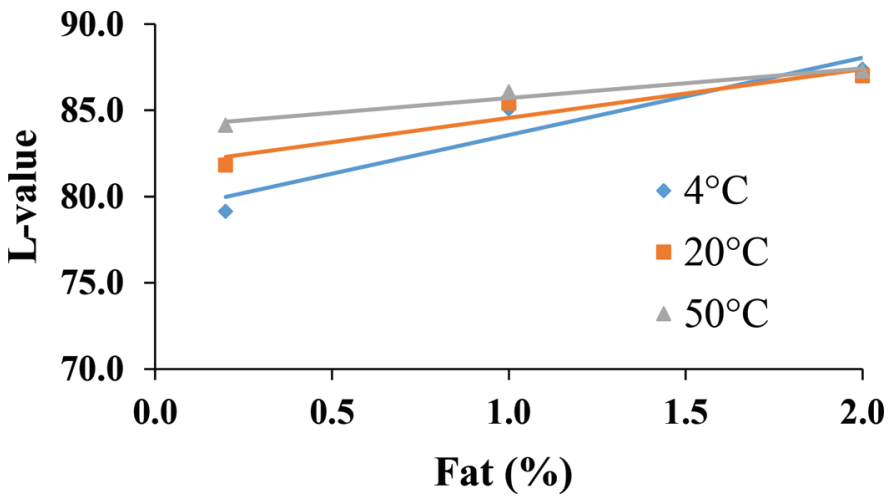

Figure 9. The L-values for 4,20 , and $50^{\circ} \mathrm{C}$ commercial HTST pasteurized milks as a function of fat percent at a $10^{\circ}$ viewer angle. $\mathrm{n}=$ 2 at each fat level for a total of 6 for each color measurement method and 18 treatments for the full experiment. Each treatment sample was tested in duplicate. Color version available online. 


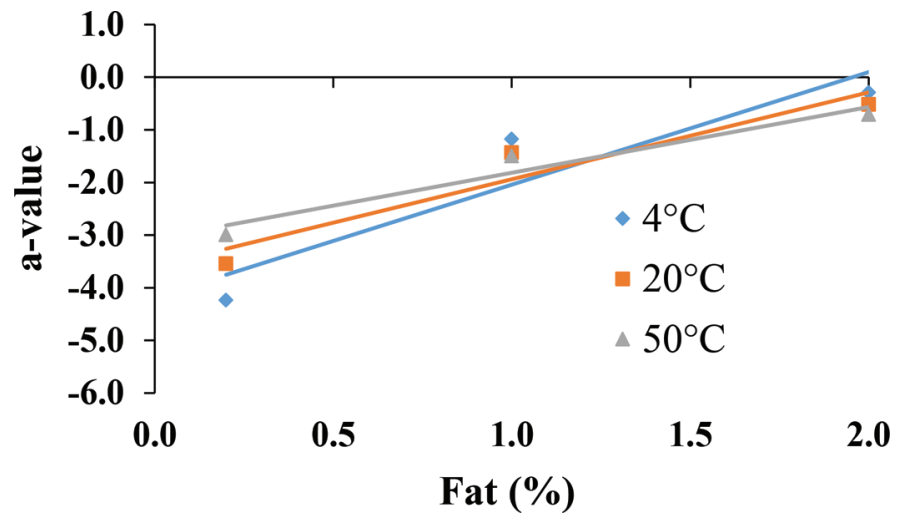

Figure 10. The a-values for 4,20 , and $50^{\circ} \mathrm{C}$ commercial HTST pasteurized milks as a function of fat percent at a $10^{\circ}$ viewer angle. $\mathrm{n}$ $=2$ at each fat level for a total of 6 for each color measurement method and 18 for the full experiment. Each treatment sample was tested in duplicate. Color version available online.

increases, change in a-value with increasing fat level is a quadratic relationship.

$\boldsymbol{b} / \boldsymbol{b}^{*}$ Values. The effect of measurement temperature explained $0.49 \%$ of the total variation of $\mathrm{b} / \mathrm{b}^{*}$ values (Table 6 ) with $50^{\circ} \mathrm{C}$ skim milk and $4^{\circ} \mathrm{C} 1$ and $2 \%$ fat milks having about 0.5 to 1 unit higher $(P<0.05)$ $\mathrm{b} / \mathrm{b}^{*}$ values than $4^{\circ} \mathrm{C}$ skim milk and $50^{\circ} \mathrm{C} 1$ and $2 \%$ fat milk, respectively (Table 5). The interaction of fat $\times$ temp explained $1.98 \%$ of the total variation of $\mathrm{b} / \mathrm{b}^{*}$ values, whereas other temperature-related interaction terms (system $\times$ temp, temp $\times$ rep, system $\times$ fat $\times$ temp, and fat $\times$ temp $\times$ rep) within the model only explained a small percentage of the variation (Table 6 ). Decreasing temperature increased $\mathrm{b} / \mathrm{b}^{*}$ values in higher fat level commercial HTST milks, whereas it decreased $\mathrm{b} / \mathrm{b}^{*}$ values in lower fat levels (Figure 11). If more fat levels (i.e., >3) were tested then it would probably become more clear that as fat level increases, the change in a-value with increasing fat level is a quadratic relationship.

Reflectance Curves. The mean reflectance curves for the skim and $2 \%$ fat commercial milks measured at 3 different milk temperatures $\left(4,20\right.$, and $\left.50^{\circ} \mathrm{C}\right)$ are shown in Figure 12. The total amount of reflected light was higher at all wavelengths for $2 \%$ fat milk than skim milk. Milk temperature had very little effect on the amount of light reflected at all wavelengths from $2 \%$ fat milk but had a large effect on the amount of light reflected from skim milk. For skim milk, the influence of milk temperature was much larger at wavelengths from 550 to $750 \mathrm{~nm}$ than at wavelengths $<550 \mathrm{~nm}$. For $2 \%$ fat milk, the reflectance from 550 to $750 \mathrm{~nm}$ was very similar at all 3 measurement temperatures. As color measurement temperature increased, the solution would expand. The approximate coefficients of expan- sion for water, fat, protein, and carbohydrate are about $0.000214,0.000727,0.000115$, and 0.000110 per degree Celsius, respectively. Fat expands more with increased temperature than water and protein and carbohydrate less than water. The total expansion of the solution going from 4 to $50^{\circ} \mathrm{C}$ would be expected to increase the solution volume by about $1 \%$. This expansion of the solution would be expected to decrease the light scattering particle density at the surface of the cuvette window and produce a decrease in L-value with increasing temperature if all other factors were equal. The opposite was actually observed (Table 5 and Figure 7).

When particles are present in a liquid and reflect light of all wavelengths uniformly, the solution will appear white. The reflective particles in the commercial milks analyzed in our study were primarily casein micelles and homogenized fat droplets. The fat droplets in homogenized milk typically have a mean particle diameter of about 0.6 to $0.8 \mu \mathrm{m}$, whereas casein micelles are about 0.15 to $0.2 \mu \mathrm{m}$ in diameter. Larger particles tend to more effectively reflect light. In skim milk almost all of the reflected light would be from casein micelles, whereas in $2 \%$ fat milk most of the reflected light would be from fat globules with some small contribution from casein micelles. It is clear from the reflectance curves for skim milk that temperature of milk during objective color measurement had a large effect on the ability of casein micelles to reflect light with much less light reflected at 4 than at 20 and $50^{\circ} \mathrm{C}$. This may be due to the dissociation of casein monomers and calcium phosphate from the casein micelles into the milk serum phase at low temperature (Rose, 1968; Downey and Murphy, 1970). In 2\% fat milk, this same dissociation of casein micelles was happening as

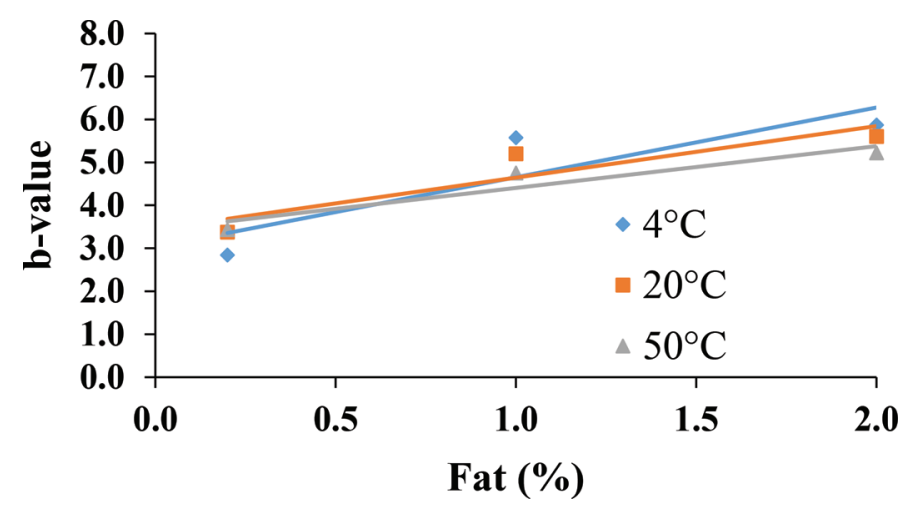

Figure 11. The b-values for 4,20 , and $50^{\circ} \mathrm{C}$ commercial HTST pasteurized milks as a function of fat percent at a $10^{\circ}$ viewer angle. $\mathrm{n}$ $=2$ at each fat level for a total of 6 for each color measurement method and 18 treatments for the full experiment. Each treatment sample was tested in duplicate. Color version available online. 


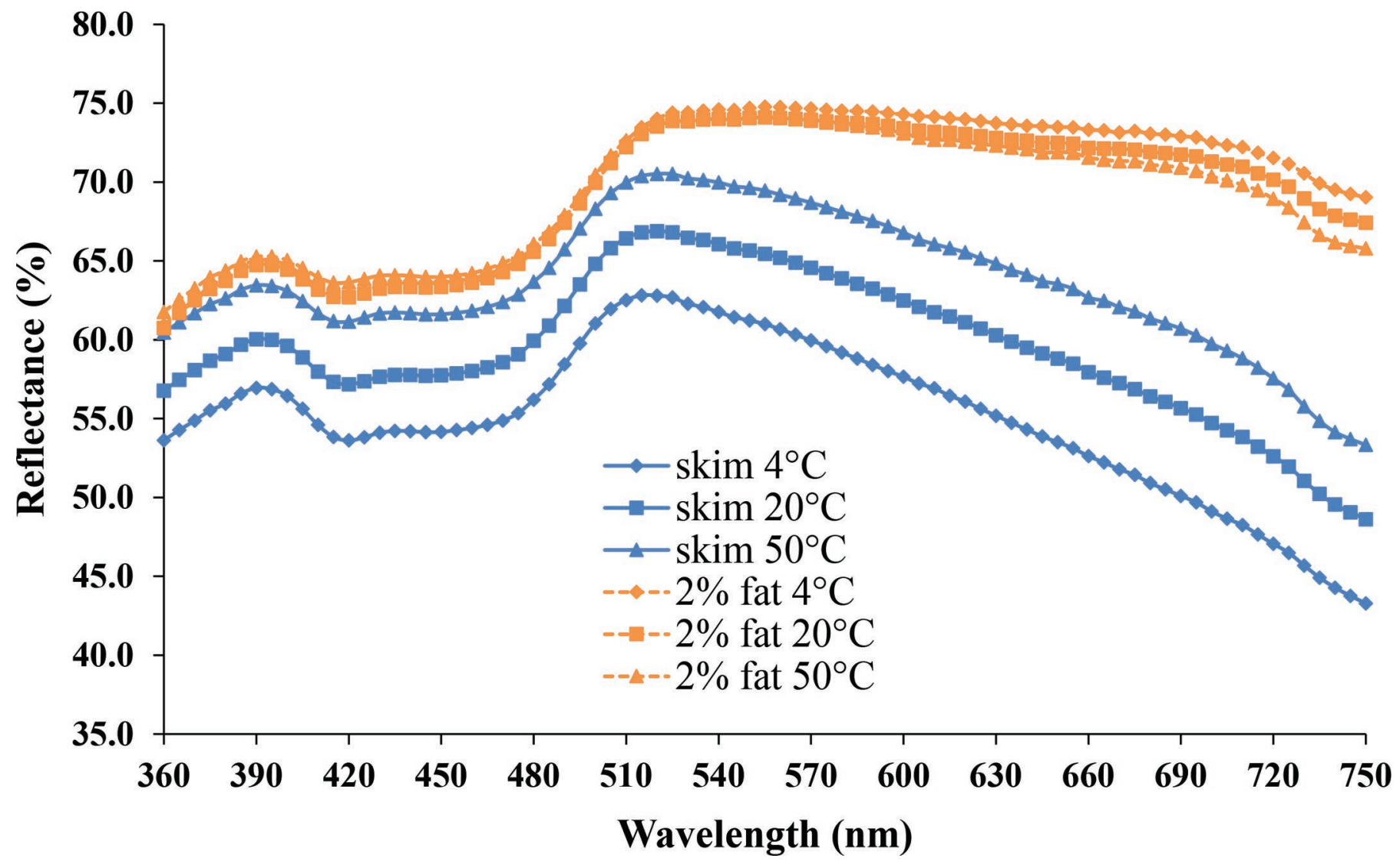

Figure 12. Mean diffuse reflectance (\%) for commercial HTST pasteurized skim and $2 \%$ fat milks at 4,20 , and $50^{\circ} \mathrm{C}$. $\mathrm{n}=1$ for each temperature within skim and within $2 \%$ fat. Each treatment sample was tested in duplicate. Color version available online.

a function of temperature. However, the larger milk fat globules reflected most of the light and therefore the temperature dependent casein micelle dissociation had minimal effect on total light reflection for $2 \%$ fat milk. It is interesting to note that over this wide range of temperature the status of the fluidity of the milk fat within fat globules differs greatly with most of the fat being solid at $4^{\circ} \mathrm{C}$, whereas most of the fat would be liquid at $50^{\circ} \mathrm{C}$. In the $2 \%$ homogenized milk, the fat globules at $4^{\circ} \mathrm{C}$ reflected more light than at $50^{\circ} \mathrm{C}$ with a higher reflectance at higher wavelength range (Figure 12). This could be due to milk fat crystallization at $4^{\circ} \mathrm{C}$ made the fat globules less spherical and thus reflect more light (Mulder and Walstra, 1974), whereas at $50^{\circ} \mathrm{C}$, the fat globules become more spherical and may lead to less light reflectance (Mulder and Walstra, 1974). The difference in reflectance curves of skim versus $2 \%$ fat milk indicates that to make skim milk appear more white and improve consumer perception of skim milk, any processing treatment or additive would need to increase reflected light much more in the range of 550 to $750 \mathrm{~nm}$ than at shorter wavelengths.

\section{CONCLUSIONS}

Color measurement viewer angle $\left(2\right.$ vs. $\left.10^{\circ}\right)$ had very little effect on objective color measures of milk-based beverages with a wide range of composition for either the Hunter or CIE color measurement system. Temperature $\left(4,20\right.$, and $\left.50^{\circ} \mathrm{C}\right)$ of color measurement had a large effect on the results of color measurement in both the Hunter and CIE measurement systems. The effect of milk beverage temperature on color measurement results was the largest for skim milk and the least for $2 \%$ fat milk. This highlights the need for proper control of beverage serving temperature for sensory panel analysis of milk-based beverages with very low fat content and for control of milk temperature when doing objective color analysis for quality control in manufacture of milk-based beverages. The Hunter system of color measurement was more sensitive to differences in whiteness among milk-based beverages than the CIE system, whereas the CIE system was much more sensitive to differences in yellowness among milkbased beverages. There was little difference between 
the Hunter and CIE system in sensitivity to green/red color of milk-based beverages. In defining milk-based beverage product specifications for objective color measures for dairy product manufacturers, the viewer angle, color measurement system (CIE vs. Hunter), and sample measurement temperature should be specified along with type of illuminant.

\section{ACKNOWLEDGMENTS}

The use of names, names of ingredients, and identification of specific models of equipment is for scientific clarity and does not constitute any endorsement of product by the authors, Cornell University (Ithaca, NY), or the Northeast Dairy Foods Research Center. The authors thank the Northeast Dairy Foods Research Center, the Department of Food Science at Cornell University, the National Dairy Council (Rosemont, IL), and the Southeast Dairy Foods Research Center (Raleigh, $\mathrm{NC)}$ for partial funding of this research. The technical assistance of laboratory staff members Chassidy Coon, Michelle Bilotta, and Sara Hatch from the Department of Food Science at Cornell University (Ithaca, NY) with analytical testing was greatly appreciated.

\section{REFERENCES}

AOAC International. 2016. Official Methods of Analysis. 20th ed. AOAC Int., Gaithersburg, MD.

Chung, S. J. 2009. Effects of milk type and consumer factors on the acceptance of milk among Korean female consumers. J. Food Sci. 74:S286-S295.

CIE (International Commission on Illumination). 1978. Recommendations on uniform color spaces, color-difference equation, psychometric color terms, Supplement No. 2 to CIE Publication No. 15. Bureau Central de la CIE.

Clydesdale, F. M. 1993. Color as a factor in food choice. Crit. Rev. Food Sci. Nutr. 33:83-101.

Corredig, M., and D. G. Dalgleish. 1999. The mechanisms of the heatinduced interaction of whey proteins with casein micelles in milk. Int. Dairy J. 9:233-236.

Donato, L., and F. Guyomarc'h. 2009. Formation and properties of the whey protein/kappa-casein complexes in heated skim milk-A review. Dairy Sci. Technol. 89:3-29.

Downey, W. K., and R. F. Murphy. 1970. The temperature-dependent dissociation of $\beta$-casein from bovine casein micelles and complexes. J. Dairy Res. 37:361-372.

Glantz, S. A., and B. K. Slinker. 2001. Multicollinearity and what to do about it. Pages 185-187 in Primer of Applied Regression and Analysis of Variance. 2nd ed. McGraw-Hill Inc., New York, NY.

Hunter Associates Laboratory. 2012. Measuring Color using Hunter L, a, b versus CIE $1976 \mathrm{~L}^{*} \mathrm{a}^{*} \mathrm{~b}^{*}$. Application Note. 1005.00. Accessed Oct. 12 2017. https://www.hunterlab.com/de/an-1005-de.pdf.

Hunter, R. S., and R. W. Harold. 1987. Uniform Color Scale. Chapter 8 in The Measurement of Appearance. 2nd ed. John Wiley and Sons Inc., New York, NY.
Kaylegian, K. E., G. E. Houghton, J. M. Lynch, J. R. Fleming, and D. M. Barbano. 2006. Calibration of infrared milk analyzers: Modified milk versus producer milk. J. Dairy Sci. 89:2817-2832.

Kaylegian, K. E., J. M. Lynch, J. R. Fleming, and D. M. Barbano. 2009. Influence of fatty acid chain length and unsaturation on midinfrared milk analysis. J. Dairy Sci. 92:2485-2501. https://doi.org/ 10.3168/jds.2008-1910.

McCarthy, K. S., K. Lopetcharat, and M. A. Drake. 2017. Milk fat threshold determination and the effect of milk fat content on consumer preference for fluid milk. J. Dairy Sci. 100:1702-1711.

Meltretter, J., S. Seeber, A. Humeny, C. M. Becker, and M. Pischetsrieder. 2007. Site-specific formation of Maillard, oxidation, and condensation products from whey proteins during reaction with lactose. J. Agric. Food Chem. 55:6096-6103.

Misawa, N., D. M. Barbano, and M. A. Drake. 2016. Influence of casein as a percentage of true protein and protein level on color and texture of milks containing 1 and 2\% fat. J. Dairy Sci. 99:5284-5304.

Mulder, H., and P. Walstra. 1974. Crystallization behavior of milk fat Chapter 3 in The Milk Fat Globule. Universities Press, Belfast, Ireland.

O'Brien, J. 2009. Non-enzymatic degradation pathways of lactose and their significance in dairy products. Pages 231-294 in Advanced Dairy Chemistry. 3rd ed. Vol. 3. P. F. Fox and P. L. H. McSweeney, ed. Springer, New York, NY.

Pangborn, R. M., K. E. Bos, and J. S. Stern. 1985. Dietary fat intake and taste responses to fat in milk by under, normal, and overweight women. Appetite 6:25-40.

Phillips, L. G., and D. M. Barbano. 1997. The influence of fat substitutes based on protein and titanium dioxide on the sensory properties of lowfat milks. J. Dairy Sci. 80:2726-2731.

Phillips, L. G., M. L. McGiff, D. M. Barbano, and H. T. Lawless. 1995a. The influence of fat on the sensory properties, viscosity and color of low-fat milks. J. Dairy Sci. 78:1258-1266.

Phillips, L. G., M. L. McGiff, D. M. Barbano, and H. T. Lawless. 1995b. The influence of nonfat dry milk on the sensory properties, viscosity and color of low-fat milks. J. Dairy Sci. 78:2113-2118.

Quiñones, H. J., D. M. Barbano, and L. G. Phillips. 1997. Influence of protein standardization by ultrafiltration on the viscosity, color, and sensory properties of skim and $1 \%$ milk. J. Dairy Sci. 80:3142-3151.

Quiñones, H. J., D. M. Barbano, and L. G. Phillips. 1998. Influence of protein standardization by ultrafiltration on the viscosity, color, and sensory properties of 2 and 3.3\% milks. J. Dairy Sci. 81:884894

Rose, D. 1968. Relation between micellar and serum casein in bovine milk. J. Dairy Sci. 51:1897-1902.

Singh, H. 2004. Heat stability of milk. Int. J. Dairy Technol. 57:111119.

Van Boekel, M. A. J. S. 1998. Effect of heating on Maillard reactions in milk. Food Chem. 62:403-414.

Wojciechowski, K. L., C. Melilli, and D. M. Barbano. 2016. A proficiency test system to improve performance of milk analysis methods and produce reference values for component calibration samples for infrared milk analysis. J. Dairy Sci. 99:6808-6827. https:// doi.org/10.3168/jds.2016-10936.

Zulewska, J., and D. M. Barbano. 2014. The impact of linear velocity and flux on performance of ceramic graded permeability membranes when processing skim milk at $50^{\circ}$ C. J. Dairy Sci. 97:26192632.

Zulewska, J., M. Newbold, and D. M. Barbano. 2009. Efficiency of serum protein removal from skim milk with ceramic and polymeric membranes at $50^{\circ}$ C. J. Dairy Sci. 92:1361-1377. 